\title{
Vulnerability and Local Innovation in Adaptation to Climate Change among the Pastoralists: Harshin District, Somali Region, Ethiopia
}

\author{
Yohannes Gebre Michael \\ Department of Geography and Environmental studies \\ Addis Ababa University, Addis Ababa, Ethiopia \\ E-mail: yohannesgmichael@gmail.com
}

Received: March 27, 2017 Accepted: May 5, 2017

doi:10.5296/emsd.v6i2.11211 URL: https://doi.org/10.5296/emsd.v6i2.11211

\begin{abstract}
The case study was made with the overall aim of understanding of pastoralist vulnerability and adaptation to climate changes. As a methodology five kebeles have been purposely selected representing pastoral and agro-pastoral farming systems in Harshin district of Somali Region in Ethiopia. The survey was conducted through semi-structured checklists with individual households and groups accounting a total of 124 people.

The major findings of the study indicated that the environmental and socio-economic dynamics are skewed to negative trends where the livelihood of the pastoral community is under a big threat. Moreover, the combinations of factors including access to resources and social institutions, livelihood practices, inappropriate technologies and policies have attributed to trigger the vulnerability to climate change among the pastoralists in general and agro-pastoralists in particular.

In adapting to the impact of climate change, pastoralists and agro-pastoralists are using wide range of group and individual local innovations, some farming practices and establishment of multi-functional grassroots institutions. Finally creating enabling policy environment for local experimentation and innovations in the framework of pastoralism and sustainability have been suggested as a point of departure in developing resilience to climate change and other pressures.
\end{abstract}

Keywords: Pastoral, Agro-pastoral, Climate change, Vulnerability, Local innovation, Adaptation, Sustainability 


\section{Introduction}

Global scientific evidences have predicted that climate changes will strongly affecting Africa in general and the arid and semi-arid areas in particular (FAO 2015, IPCC 2014, Adger et-al 2007, Christensen et-al 2007, Haile 2005). Similarly African farmers and pastoralists are aware of climate change as one of the many drivers of change in their landscape and livelihoods (Apata et-al, 2009).

Currently the pastoralist population in Africa is estimated 268 million, which is over a quarter of the total population. It also accounts about $43 \%$ of the total area and contributes up to $44 \%$ of GDP of African countries (African Union 2010). In Ethiopia the current estimates of the pastoralists population is more than 15 million and assume to cover more than $60 \%$ the country and expected to increase with climate change as many rural community will shift from crop to livestock rearing as adaptation to climate change (Spore 2008).

In the other hand the high vulnerability to climate change has stimulated the rural community to experiment and develop indigenous innovation as resilience to climate change. The wide range of cost-effective, participatory and sustainable adaption strategies includes early warning systems, diversity of crop and livestock, mobility, social networks and customary systems of governances (Nakashima et-al 2012, Pavanello 2009). For example mobility of livestock has multiple functions of optimizing the spatial and temporal variability of rainfall and biodiversity, avoiding risks of livestock diseases and resource base conflicts. The seasonal cross border mobility is based on the principles of territorial fluidity and reciprocity and the strong social safety nets among the clan and sub-clan as a collective and collaborative innovation (Yohannes et-al 2011, Rettberg 2010, Scoones 2004). Similarly, rearing of different livestock (grazers and browsers) has multiple roles on the optimal use of resources, drought resistance, food security and economic values. Moreover, customary institutions play fundamental role in assuring good governance, mange resource and facilitating social safety nets (Rettberg 2010, Davies and Nori 2008, Scones 2004, Pelling and High 2003). Similarly the AU policy framework for pastoralism in Africa has also clearly underlined the rationality of pastoralism and the need to empower pastoralists to assure food security and sustainable resource management. Moreover, the pastoral rangelands have a greater potential to store carbon below ground than any other ecosystem (AU 2010, Davies and Nori 2008).

However, today about $10 \%$ of Ethiopia's population is chronically food insecure and this figure rises to more than $15 \%$ during prolonged drought and flooding (Birara et-al 2015, IPCC 2014, AFI 2012). Accordingly the pastoralists' areas in Ethiopia are known for the different ecological and human crisis such as environmental degradation, conflicts, migration and chronically dependency on food aid. The problem has been compounded with the land grabbing of pastoral areas for commercial farming and national parks (Rettberg 2010, Little-et-al 2010, Little et-al 2010, Yohannes and Mebratu 2009, Hesse and MacGregor 2006). Other factors related for the crises in pastoral areas is usually related to population pressure, poor land management, tragedy of commons and backwardness of the society (Birara et-al 2015, ATA 2010, Kurukulasuriya et-al 2006, Butt et-al 2005, Markakis 2004). However, some have underlined the fundamental cause revolves around the policy defects that has 
marginalized the pastoralists not to exercise their deep rooted indigenous practices to adapt to different changes (FAC-CAADO 2012, Nakashima et-al 2012, Hesse and MacGregor 2006, Behnke 1985 ).

According to Devereux (2006), drought as such is not making pastoralists vulnerable but rather the increasing marginalization of their drought-response mechanisms. Restriction on mobility of people and animals, intensification of conflicts and control of cross-border trade and defective tenure policy are some of the threats. Moreover, it was underlined that land use changes from rangeland to cropping land, the expansion of invasive plants, such as Prosopis species, expansion of settlements and expansion of private land enclosures have led to deterioration of pastoral livelihoods (Mebratu 2009, Hesseand MacGregor 2006, Yohannes and Waters-Bayer 2002).

Similarly an intensive empirical case study in the Afar pastoral community of Ethiopia underlined that the political and economic marginalization of the Afar community is the fundamental causes of vulnerability than drought per se. In other words the government policy of sedentary farming of the mobile pastoralists, the occupation of prime grazing land by the state owned sugarcane plantation and the disarmament of the pastoral community are the fundamental causes of the Afar pastoralist crisis to food insecurity (Rettberg 2010). Furthermore some agencies those work closely with pastoralist groups around the world felt that the challenge of climate change seems insignificant to many pastoralists who are faced with extreme political, social and economic marginalization (Davies and Nori 2008).

Generally in the arid and semiarid context addressing the impact of climate change requires a combination of technological and institutional innovation with the framework of the pastoral socio-economic conditions (Taylor et-al 2012). Therefore, the overall aim of the case study is to understand the vulnerability of pastoralists to climate change and other pressures and document their innovative adaption to climate change.

\section{Research Methodology}

\subsection{Material and Approaches}

The case study is conducted in Harshin woreda (district) of Somalia Region of Ethiopia purposely due to the practice of two farming practices (mobile pastoralists and agro-pastoralist) and wide spreading innovative practices in adaption to climate change and other pressures (see Figure 1).

Accordingly from the mobile pastoralists considering indigenous practices and proximity, three pilot kebeles were selected namely Aranarny, Bali Abad and Lankerta. Similarly from agro-pastoral two kebeles namely Harshin and QudhaRamalle were selected mainly due to their proximity and some development interventions. From each kebele individual and group discussions were made with the help of semi-structured checklists and resource persons from the locality helps in facilitation. In each Keble a transect method is used who ever meet during the walk was randomly consulted with strategy of representing different farming practice, wealth rank groups, sex, age and sub-clan. Similarly the group discussions with elders, leaders, adults, youth and women were made after the individual discussions during 
the transect walk. Each group discussions were covering three to seven people. As shown in table 1 a total of 124 people were consulted during the individual and group discussions and $44 \%$ of the pilot samples were female. Moreover, field observations of land use/covers and development interventions at different kebeles were exercised with some checklists. However, a clear cut demarcation of the pastoral and agro-pastoral is sometimes difficult due to the practice of family splits and interdependency of the two systems.

Table 1. Sample population

\begin{tabular}{|c|c|c|c|c|}
\hline Farming practice & \multirow[t]{2}{*}{ Pilot Kebeles } & \multicolumn{2}{|c|}{ Individuals } & \multirow[t]{2}{*}{ Group discussions } \\
\hline \multirow[t]{4}{*}{ Pastoralist } & & Male & Female & \\
\hline & Aranarny & 7 & 3 & $\begin{array}{l}5 \text { Male (elder and leaders) } \\
4 \text { Women (adult/ elder) }\end{array}$ \\
\hline & Bali Abad & 10 & 5 & $\begin{array}{l}6 \text { Male (elders, leaders, youth) } \\
3 \text { women (adult) }\end{array}$ \\
\hline & Lankerta & 9 & 5 & 3 women (elders/adult) \\
\hline Total & & 26 & 13 & 21 \\
\hline \multirow[t]{2}{*}{ Agro-pastoralist } & Harshin & 12 & 8 & $\begin{array}{l}5 \text { Men (elderly, leaders, adult) } \\
9 \text { women (youth, Adult, elders) }\end{array}$ \\
\hline & Qudha-Ramalle & 8 & 10 & $\begin{array}{l}7 \text { male (elders, leaders, adults) } \\
5 \text { women (elders) }\end{array}$ \\
\hline Total & & 20 & 18 & 26 \\
\hline Grand total & 124 & 46 & 31 & 47 \\
\hline
\end{tabular}

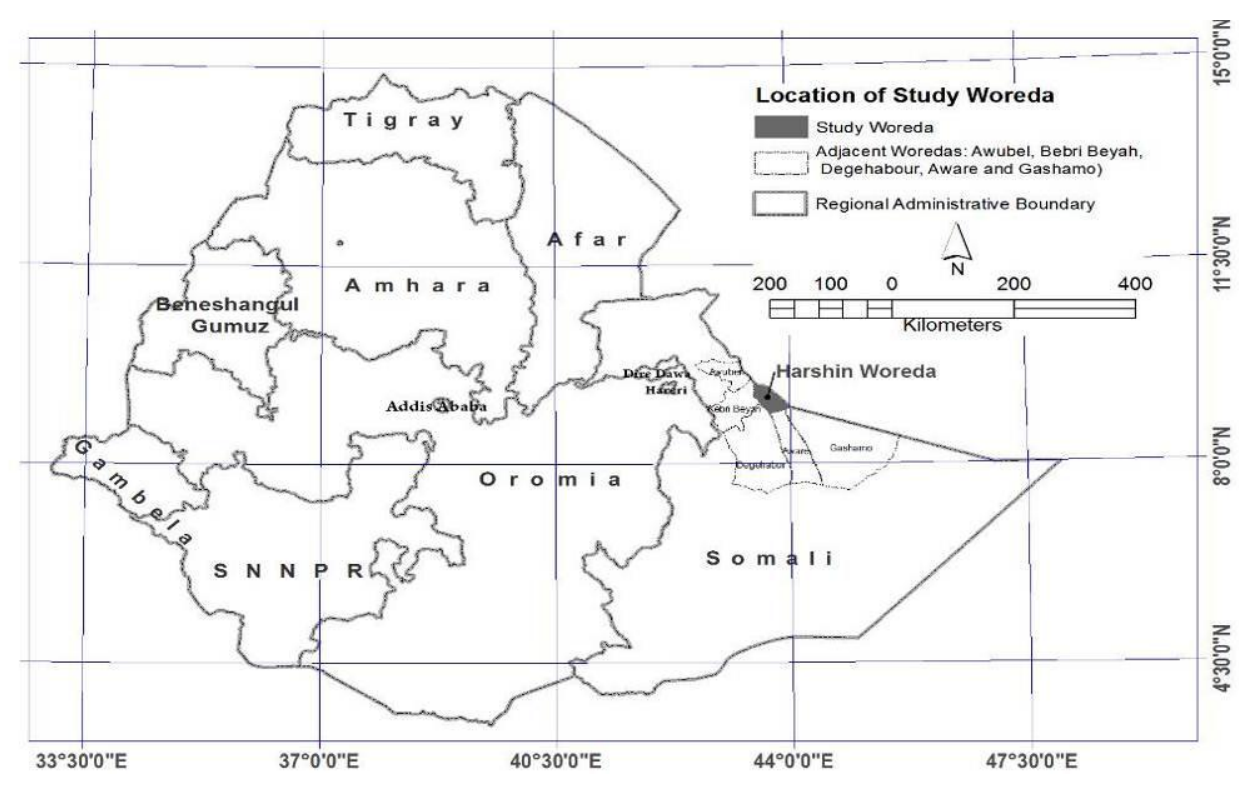

Figure 1. The study areas

\subsection{Profile of the Study Area}

Harshin is one of six woreda (district) in Jijiga zone of Somali Region which is $120 \mathrm{kms}$ East of Jijiga town and it has 32 kebeles (see Figure 1). The study area is an arid and semiarid with 


\section{Mll Macrothink}

limited and unreliable rainfall with two peak rainy seasons of $G u$ (April-May) and Deyer (October-December). In some localized places a small rain is received between August and September (Karan). Based on the metrological station records of at Harshin town from 1979 to 2014 the average rainfall is about $150 \mathrm{~mm}$ and this ranges from $40 \mathrm{~mm}$ to $300 \mathrm{~mm}$ per annum (NMA 2015). As shown in figure 2 the annual rainfall pattern is erratic and in decreasing trend. However, a disaggregated seasonal, monthly and daily rainfall analysis might be good indicators to the intensity and distribution of rainfall in the arid and semi arid areas. Similarly the average temperature ranges from 27 to $35^{\circ} \mathrm{C}$.

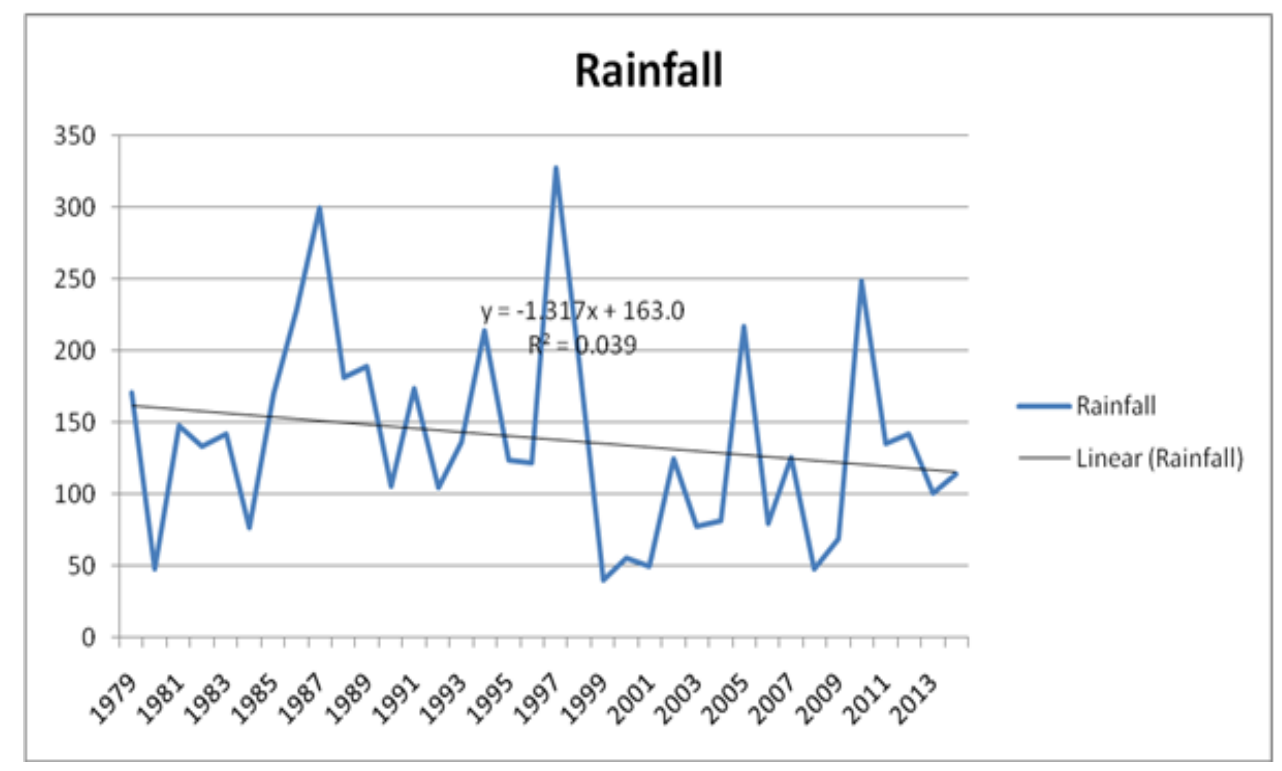

Figure 2. Trends in annual rainfall in Harshin (1979-2014)

Source: NMA, 2015

\subsection{Livelihoods}

According to the 2007 census the total human population of the Harshin woreda was 80,215people (CSA 2007). The average family size is 7.4 persons. The family size ranges from 6 to 14 people and the better-off with two or more wives have the highest family size. The dominate clans in the study areas are Isaaq and the sub-clan includes Awol, Ayub, Arab and Togchale.

Based on the household and group discussions the major activities under the two systems have been identified as shown in table 2. Generally the livelihood practices have different implications. First under the two farming systems livestock and livestock products are the backbone of the economy. Usually the savings from the different incomes or remittance are in the form of livestock, which is rational as no interest is expected from saving in the bank as a Muslim community. Secondly the different livelihood activities are not far from the vulnerability to climate change. Thirdly some of the livelihood bases are synergy to each other as the case of livestock and livestock products and trade, while others are conflicting and triggering vulnerability and vicious circle of poverty as the case of charcoal making, 
expansion of private enclosures and dependency on safety nets.

Historically, the agro-pastoralists are the poor who have dropped out from pastoralism and migrate to per-urban areas for food assistance and employment opportunities. They usually settled on enclosure of small plots around the peripheral of the peri-urban areas and owned few shoats, exercising opportunistic farming, sale of fodder and fuel wood. Gradually with the government policy support for crop farming and settlements the private enclosures has been expanding. The policy implementation is complemented with the establishment of social services including water development, health services, schools, farming extension services and safety net support programs.

Table 2. Livelihood practices

\begin{tabular}{|c|c|c|c|}
\hline \multirow[t]{2}{*}{ Livelihood bases } & \multicolumn{2}{|c|}{ Farming practices } & \multirow[b]{2}{*}{ Remark } \\
\hline & Agro-pastoral & Pastoral & \\
\hline Livestock rearing & $\begin{array}{l}\text { Dominantly shoats } \\
\text { and few cattle ( dairy/ } \\
\text { plough) }\end{array}$ & $\begin{array}{l}\text { Dominantly } \\
\text { shoats, camels and } \\
\text { few cattle. }\end{array}$ & $\begin{array}{l}\text { The cattle population has decline due to } \\
\text { the prolonged drought. Relatively } \\
\text { mobile pastoralists have wider species } \\
\text { and numbers. }\end{array}$ \\
\hline Crop farming & \begin{tabular}{ll|} 
Under & private \\
enclosure
\end{tabular} & Not practiced & $\begin{array}{l}\text { Usually related with poor wealth rank } \\
\text { and characterized by failure due to } \\
\text { drought }\end{array}$ \\
\hline Horticulture & $\begin{array}{l}\text { Few } \\
\text { supplementary } \\
\text { irrigation from Haffir } \\
\text { dam }\end{array}$ & $\begin{array}{l}\text { Private enclosure } \\
\text { highly discouraged }\end{array}$ & A push from government and NGOs \\
\hline Dairy farming & $\begin{array}{l}\text { Widespread due to } \\
\text { high demand from } \\
\text { urban population }\end{array}$ & $\begin{array}{l}\text { Gradually } \\
\text { developing with } \\
\text { self-help women } \\
\text { groups }\end{array}$ & $\begin{array}{l}\text { Wide spreading due to market } \\
\text { connections }\end{array}$ \\
\hline Water selling & \multicolumn{2}{|c|}{$\begin{array}{l}\text { Declining of Birkas due to prolonged } \\
\text { drought and introduction of communal } \\
\text { water sources by the government and NGOs }\end{array}$} & $\begin{array}{l}\text { Undermining local initiatives in water } \\
\text { development is not only discourage } \\
\text { range of options and it also create } \\
\text { dependency syndrome }\end{array}$ \\
\hline $\begin{array}{l}\text { Fodder selling/ } \\
\text { pasture renting }\end{array}$ & $\begin{array}{l}\text { Wide spreading with } \\
\text { the expansion of } \\
\text { private enclosures }\end{array}$ & $\begin{array}{l}\text { Slowly expanding } \\
\text { with government } \\
\text { support }\end{array}$ & $\begin{array}{l}\text { Conflict between private and communal } \\
\text { grazing, restriction of mobility, spread } \\
\text { of livestock diseases and } \\
\text { marginalization of customary institution } \\
\text { in resource management }\end{array}$ \\
\hline Petty trade & $\begin{array}{l}\text { Livestock and } \\
\text { livestock products and } \\
\text { crop, petty trade }\end{array}$ & $\begin{array}{l}\text { Mainly livestock } \\
\text { (domestic /cross } \\
\text { border) }\end{array}$ & Complementary to the livelihoods \\
\hline Charcoal making & $\begin{array}{l}\text { Among the poor and } \\
\text { medium }\end{array}$ & $\begin{array}{l}\text { Dropouts from } \\
\text { system }\end{array}$ & $\begin{array}{l}\text { Wide spreading with prolonged drought } \\
\text { and limited government emergency } \\
\text { support }\end{array}$ \\
\hline Remittance & Usually mediur & n/better off & $\begin{array}{l}\text { Contribution to restocking and } \\
\text { livelihood diversification }\end{array}$ \\
\hline $\begin{array}{l}\text { Safety net } \\
(\text { Government/NGO) }\end{array}$ & $\begin{array}{l}\text { Short term and very } \\
\text { limited number of } \\
\text { people benefited }\end{array}$ & $\begin{array}{l}\text { Almost none } \\
\text { existence due to } \\
\text { remoteness }\end{array}$ & $\begin{array}{l}\text { Not complemented to the traditional } \\
\text { social safety net }\end{array}$ \\
\hline
\end{tabular}




\section{Discussions and Results}

\subsection{Community Perceptions of Dynamics in Their Locality}

The series of pastoralist group discussions in the different kebles on the dynamics of socio-economic and environment indicate that some are in increasing or decreasing trend, while others are fluctuating. As shown in table 3 the components in increasing trend includes drought, diseases (human and livestock) and land degradation. Similarly the decreasing trend components include forest biodiversity, livestock mobility, crop production and role of customary institutions. Generally the factors are not mutually exclusive and climate change is only one of many drivers of changes in the local community. Moreover, the increasing and decreasing trend implies pastoralism is under a big threat with the wider range of vulnerability and decline of resilience to climate change. However, mobile pastorlism is in better position to resilience than the agro-pastoralist mainly due to access to wider rangelands and diversity of livestock. Similarly the increase of water points is unevenly distributed and biased to agro-pastoral areas. The concentrated water points attract many livestock beyond the local boundary under the principles of reciprocity and this attributes to overgrazing, land degradation and spread of livestock diseases.

Table 3. Opportunities and challenges perceived by pastorals and agro-pastoralists

\begin{tabular}{|c|c|c|c|c|}
\hline Indicators & Trends & Causes and impacts & Remarks & Literature review \\
\hline Drought & Increasing & $\begin{array}{l}\text { Frequent and prolonged } \\
\text { drought is accompanied by } \\
\text { shortage of fodder and spread } \\
\text { of livestock diseases. This has } \\
\text { resulted death of livestock, in } \\
\text { some localities the cattle } \\
\text { population is totally } \\
\text { diminished and many have } \\
\text { dropout from pastoralism }\end{array}$ & \multirow{3}{*}{$\begin{array}{l}\text { Pastoralist proposed } \\
\text { revitalization of } \\
\text { communal rangeland } \\
\text { management and } \\
\text { widespread development } \\
\text { of water points and } \\
\text { veterinary services } \\
\text { beyond local boundary } \\
\text { This is mainly attributed } \\
\text { due to high variability of } \\
\text { rainfall, unplanned water } \\
\text { developments trigger } \\
\text { livestock concentration } \\
\text { and limitation of mobility }\end{array}$} & $\begin{array}{l}\text { Ringer 2008, } \\
\text { NMA 2007, Sugule } \\
\text { and Robert } 1998\end{array}$ \\
\hline $\begin{array}{l}\text { Plant } \\
\text { biodiversity }\end{array}$ & Decreasing & $\begin{array}{l}\text { Declining due to deforestation } \\
\text { for fuel and charcoal, } \\
\text { expansion of settlements and } \\
\text { prolonged drought. Due to } \\
\text { limited pasture and nutritional } \\
\text { values livestock become low } \\
\text { resilience to drought diseases, } \\
\text { prolonged restocking and } \\
\text { decline of household economy }\end{array}$ & & $\begin{array}{l}\text { Sead 2007, } \\
\text { Talascan } \\
\text { 2009,Haggman } \\
\text { 2006, Manger and } \\
\text { Ahmed 2000 }\end{array}$ \\
\hline $\begin{array}{l}\text { Spread of } \\
\text { livestock } \\
\text { disease }\end{array}$ & Increasing & $\begin{array}{l}\text { Mainly with shortage of } \\
\text { pasture, concentration of } \\
\text { livestock on limited pasture } \\
\text { areas and water points which } \\
\text { trigger spread of livestock } \\
\text { diseases and decline of } \\
\text { livestock ownership and } \\
\text { dependency on emergency } \\
\text { support }\end{array}$ & & $\begin{array}{lr}\text { Yohannes } & 2015, \\
\text { Sead } & 2007, \\
\text { Devereux } & 2006,\end{array}$ \\
\hline $\begin{array}{l}\text { Livestock } \\
\text { diversity }\end{array}$ & Decreasing & $\begin{array}{l}\text { Livestock diversity per } \\
\text { household is declining both in } \\
\text { the pastoral and agro-pastoral } \\
\text { areas. In the agro pastoral }\end{array}$ & $\begin{array}{l}\text { Camel have a good } \\
\text { resilience to drought, } \\
\text { while Shoats have quick } \\
\text { recovery and easy }\end{array}$ & $\begin{array}{l}\text { Yohannes } \\
\text { Mebratu }\end{array}$ \\
\hline
\end{tabular}




\begin{tabular}{|c|c|c|c|c|}
\hline & & $\begin{array}{l}\text { dominantly shoats with few } \\
\text { milking cows and oxen, while } \\
\text { in the pastoral areas shoats and } \\
\text { camel are dominating and } \\
\text { Cattle population is } \\
\text { diminishing }\end{array}$ & marketing & Simpkin 2005 \\
\hline $\begin{array}{l}\text { Water } \\
\text { availability }\end{array}$ & Increasing & $\begin{array}{l}\text { Development of different water } \\
\text { points by the government and } \\
\text { NGOs around settlements. This } \\
\text { concentration of water sources } \\
\text { has created overgrazing and } \\
\text { spread of diseases }\end{array}$ & $\begin{array}{l}\text { Proposed an even } \\
\text { distribution with } \\
\text { integrated approach of } \\
\text { the communal range } \\
\text { lands within and beyond } \\
\text { local boundary and } \\
\text { empower the customary } \\
\text { institutions to mange. }\end{array}$ & $\begin{array}{l}\text { EPEMRDA 2011, } \\
\text { Simon and Gezu } \\
2011 \text {, Napier and } \\
\text { Solomon 2011, } \\
\text { Devereux 2006, } \\
\text { Sugule and Robert } \\
1998\end{array}$ \\
\hline $\begin{array}{l}\text { Livestock } \\
\text { mobility }\end{array}$ & Decreasing & $\begin{array}{l}\text { Declining as the result of } \\
\text { expansion of enclosures, } \\
\text { settlements and decline of } \\
\text { livestock size per household } \\
\text { and dominantly shoats. }\end{array}$ & $\begin{array}{l}\text { Strengthening } \\
\text { traditional practices of } \\
\text { fluidity of boundary and } \\
\text { reciprocity among the } \\
\text { pastoralists while } \\
\text { discouraging private } \\
\text { enclosure with } \\
\text { appropriate land policy in } \\
\text { the pastoral areas }\end{array}$ & $\begin{array}{lr}\text { Napier } & \text { and } \\
\text { Solomon } & 2011, \\
\text { Simon and } & \text { Gezu } \\
2011, & \\
\text { Devereux 2006, } & \\
\text { Haggman 2006 }\end{array}$ \\
\hline $\begin{array}{l}\text { Land } \\
\text { degradation }\end{array}$ & Increasing & $\begin{array}{l}\text { Overgrazing with limited } \\
\text { mobility, deforestation with } \\
\text { expansion of settlements, } \\
\text { cropping, fuel wood and } \\
\text { charcoal making. }\end{array}$ & $\begin{array}{l}\text { Management of the } \\
\text { rangelands, } \\
\text { intensification of fodder } \\
\text { production on existing } \\
\text { enclosures and strengthen } \\
\text { grassroots institutions }\end{array}$ & $\begin{array}{l}\text { Sead 2007, Sugule } \\
\text { and Robert } 1998\end{array}$ \\
\hline $\begin{array}{l}\text { Resource } \\
\text { base conflict }\end{array}$ & Increasing & $\begin{array}{l}\text { The fundamental causes are the } \\
\text { private enclosures, unplanned } \\
\text { settlements and Charcoal } \\
\text { making. Shortage of pasture, } \\
\text { restriction of mobility and } \\
\text { decline of livestock asset and } \\
\text { dropouts from pastorlism }\end{array}$ & $\begin{array}{l}\text { Revitalizing of customary } \\
\text { rules and regulations that } \\
\text { contribute to rangeland } \\
\text { management and enforce } \\
\text { rules and regulations to } \\
\text { unplanned enclosures and } \\
\text { settlements }\end{array}$ & $\begin{array}{l}\text { Simon and Gezu } \\
2011, \text { Napier and } \\
\text { Solomon } 2011, \\
\text { Unruh } 2006 \\
\text { Haggman 2006, } \\
\text { Sugule and Robert } \\
1998\end{array}$ \\
\hline $\begin{array}{l}\text { Crop } \\
\text { production }\end{array}$ & Decreasing & $\begin{array}{l}\text { Due to drought and unreliable } \\
\text { rainfall crop failure and } \\
\text { frequent seeding is a rule, } \\
\text { except under the } \\
\text { supplementary irrigation } \\
\text { around the Haffir dames }\end{array}$ & $\begin{array}{l}\text { In arid and semi-arid } \\
\text { areas pasture and } \\
\text { livestock production is } \\
\text { more appropriate than } \\
\text { crop with risks. }\end{array}$ & $\begin{array}{ll}\text { Simon and Gezu } \\
\text { 2011, Sead } 2007, \\
\text { Devereux } & 2006, \\
\text { Funk et. al. } & 2005, \\
\text { Hogg } 1997 & \end{array}$ \\
\hline $\begin{array}{l}\text { Diversity of } \\
\text { livelihoods }\end{array}$ & Increasing & $\begin{array}{l}\text { There is some diversity with } \\
\text { the split of the family and } \\
\text { connecting to market. However } \\
\text { the dominate livelihood } \\
\text { practice is revolving around } \\
\text { livestock and livestock } \\
\text { products, while many are } \\
\text { dependent on charcoal sale and } \\
\text { safety nets }\end{array}$ & $\begin{array}{l}\text { Strengthen the range } \\
\text { management } \\
\text { livestock production } \\
\text { which has an economic, } \\
\text { social and ecological } \\
\text { potential }\end{array}$ & $\begin{array}{l}\text { Yohannes 2015, } \\
\text { Devereux } 2006\end{array}$ \\
\hline $\begin{array}{l}\text { Role of } \\
\text { customary } \\
\text { institutions }\end{array}$ & Decreasing & $\begin{array}{l}\text { With the decline of power of } \\
\text { customary institutions problem } \\
\text { of land degradation and }\end{array}$ & $\begin{array}{l}\text { Empowering customary } \\
\text { institution is an access to } \\
\text { leadership of elders with }\end{array}$ & $\begin{array}{l}\text { Napier and } \\
\text { Solomon, 2011 }\end{array}$ \\
\hline
\end{tabular}




\begin{tabular}{|l|l|l|l|l|}
\hline & conflicts increase & $\begin{array}{l}\text { deep knowledge and skill } \\
\text { in common resource } \\
\text { management and assuring } \\
\text { social safety nets }\end{array}$ & $\begin{array}{l}\text { Simon and Gezu } \\
\text { 2011, Unruh 2006 }\end{array}$ \\
\hline
\end{tabular}

Regarding the opportunities and challenges the group and individual pastoralists and agro-pastoralists have reflected the following opinions:

"The construction of Haiffir dam in our locality helps to produce some irrigated vegetables for consumption and sale. However, when the neighboring communities including Somaliland are facing shortage of water for their livestock they consume the water from the Haffir dam (reciprocity) and irrigation becomes unreliable" Agro-pastoralist women from Harshin

"We seed some improved crops annually but usually the rain fails in the middle of the growing period and we harvest some biomass if not grain" Agro-pastoralist from Qudha-Ramalle.

"I have two wives and eleven children, one of my wives is in the bush with some camels and shoats and my second wife is in this village. I have some shoats, milking cows, one Birka and big private enclosure mainly for grazing and fodder production. Some of the children are also sent to school. The split of the family under the two locations has helped to complement, diversify livelihood and maximizing the opportunities" One of the pastoralist in Lankerta

"After we lost gradually our livestock due to drought and disease in the last five years, we migrate with our three children to the town of Hrashin. Our clan has allocated us with a small land for settlement and some fodder production. My husband is generating income from charcoal sale while I am engaged on sale of Khat. Life is from hand to mouth" Agro-pastoralist woman from Harshin

"In the past twenty years the two rainy seasons ( $G u$ and Deyer) are either normal or alternatively failed. Under this condition quick recovery or restocking was not difficult. However, today due to prolonged drought both rainy seasons are failing and result death of livestock and dropping from pastoralism. Government assistance is essential in restocking and facilitating mobility” Elderly pastoralist from Bali Abad

"The major factor for the food crisis in our locality is the expansion of private enclosures and settlements in the prime rangelands. This has resulted shortage of pasture, restriction of mobility, expansion of livestock disease and deaths" Pastoralists from Aranarny

"We lost most of our animals gradually due to drought and disease. Finally we move to Harshin town with some small animals. Some were sold to establish a small shop with consumable goods while the remaining animals are under fatting in the private enclosures. Our two children are also attending schools and gradually improving our businesses" Agro-pastoralist from Harshin

"The bad time for pastoralists has come. Today elders are marginalized and the fate of 
pastoralism is under big threat. There are no rules and regulations when individuals are making charcoal, enclosing private land, settling anywhere and establishing water points without considering the distribution of rangelands. Elderly pastoralists from Bali Abad

Generally the water development that does not consider spatial distribution across the border with the strategy of reciprocity has become a threat than opportunity for the locality. Similarly the land security issue, expansion of settlements and marginalization of the customary institutions are the fundamental causes of conflicts and vulnerability to the impact of climate change.

\section{Community Vulnerability to Climate Change}

The community in the study area is heterogeneous in wealth, power and accesses to natural resource bases, hence their vulnerability to climate change and adaptations are also variable. Usually the IDPs, landless, women heads and the elderly and children are the most vulnerable to climate vulnerability mainly due to limited access to resources and range of options.

Generally the vulnerability indicators of the pastoral community can be broadly classified as follows:

Type of animal ownership: Those who dominantly rearing cattle and sheep the agro-pastoralist are more vulnerable than pastoralist dominantly rearing camels and goats that have resilience to shortage of water better access to wider range of options for pasture across the border. Moreover, camel assures continuous supply of milk for consumption, sale and for transportation of commodities and water. However, it will be a challenge how such browsers with long threshold of mobility will adapt to the expansion of private enclosures.

Clan membership: In the study area the dominate clan is Isaac with many sub-clans yet during any livelihood crisis the pastoralist belonging to the majority has more access to the social safety net (livestock contribution and access to food and cash) than the minority. When a member of the sub-clan lost his/her livestock due to drought and diseases usually the better-off contribute small shoots and milking cows or camel to the family until they recover and restock. Unfortunately due to the prolonged drought many of the better-off are also losing their livestock assets and forced to depend on relief support.

Land ownership: Size of private land ownership is also a fundamental indicator for vulnerability. Those pastoralists with big land enclosures who are not necessarily dropouts are consuming pasture in the enclosure for their own livestock and fodder sale. They also rent the land for others to graze their livestock. Some have more than two enclosures at different locations, while the poor dropouts have very small plot and some without any plot. For example many pastoralists coming from other areas due to drought and some cooperatives dealing with livestock fatting are renting such private plots for pasture. However, the increasing trend of land privatization has some undesired out comes to the foundation of pastoralism including communality, mobility, reciprocity and sustainability.

Birka ownership: is a one of the fundamental influential factors of vulnerability to climate change for at least two reasons; first owners of Birkas have no expenses for watering their 


\section{Ml Macrothink}

livestock mainly in the drought period, while the non owners are selling their livestock to cover the expense for watering their livestock. Some of the Birkas owners have more than two locations at different villages to water their livestock. Secondly the Birkas are source of income and during the peak drought the cost of barrel water (100 liters) is about three US dollar. Therefore, the savings of livestock with available water and generating of additional income from Birkas attribute to less vulnerability to climate change. However, the Haffir dams and bore holes constructed by the government and NGOs are usually concentrated around settlements and attracted many livestock from neighboring and cross border pastoralists and become a threat for vulnerability (overgrazing, land degradation and spread of diseases). It also discourages local initiatives of Birkas construction at different spatial locations as the Haffirdam and borehole water are relatively cheaper and subsidized by the government or NGOs.

Membership in self-help or cooperatives: Initially NGOs like Oxfam GB play fundamental role in the establishment of self-help and cooperatives in Harshin area for decades. Gradually the local government is supporting these initiatives. Most of the self-help groups and cooperatives are engaged on dairy farming, livestock fatting, and establishment of small shops and sale of vegetables. Some are exporting goats abroad. Usually the group formation is dominated by women and strong among the agro-pastoral areas and gradually diffusing to the pastoral areas. Hence those members of the cooperatives have multiple advantages including information on different business opportunities, savings and access to credit, diversification of livelihoods, access to different types of training by government and NGOs. Relatively they are having strong resilience to climate change and other pressures.

Livelihood engagement: Usually the poor and the middle income Agro-pastoralists are engaged on charcoal making and some are organized in a self-help group (pate 1). These charcoal makers have to travel long distance due to the continuous deforestation and conflict with the local pastoral community who are losing their rangelands due to deforestation and land degradation. Generally the deforestation compounded with the prolonged drought brought both the pastoralist and agro-pastoralists in the vicious circle of poverty.

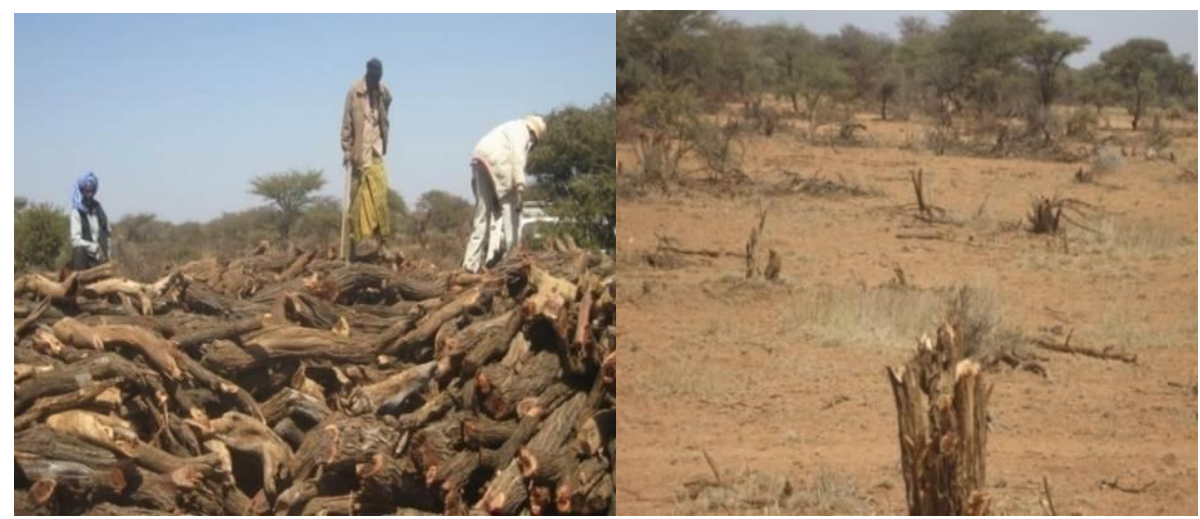

Plate 1. Deforestation due to commercialization of charcoal 
In appropriate technology: The construction of water harvesting technologies like the Haffirdam by the NGOs and government has played fundamental role in watering the livestock and for human conceptions. Usually the design of the dam is seventy meters in width and hundred meters in length and three meters in depth. It has also a silt trap as a package. However, in some localities the Haffir dames are constructed as emergency intervention prior to upstream treatment with enclosure and afforestion, hence the Haffir dame is silited up in one year as shown in plate 2. This has at least two implications; first the pastoralists become more vulnerable due to the defective technology and forced to travel long distance and cover water expenses. Secondly they lose trust on the government and NGOs who brought defective technology.

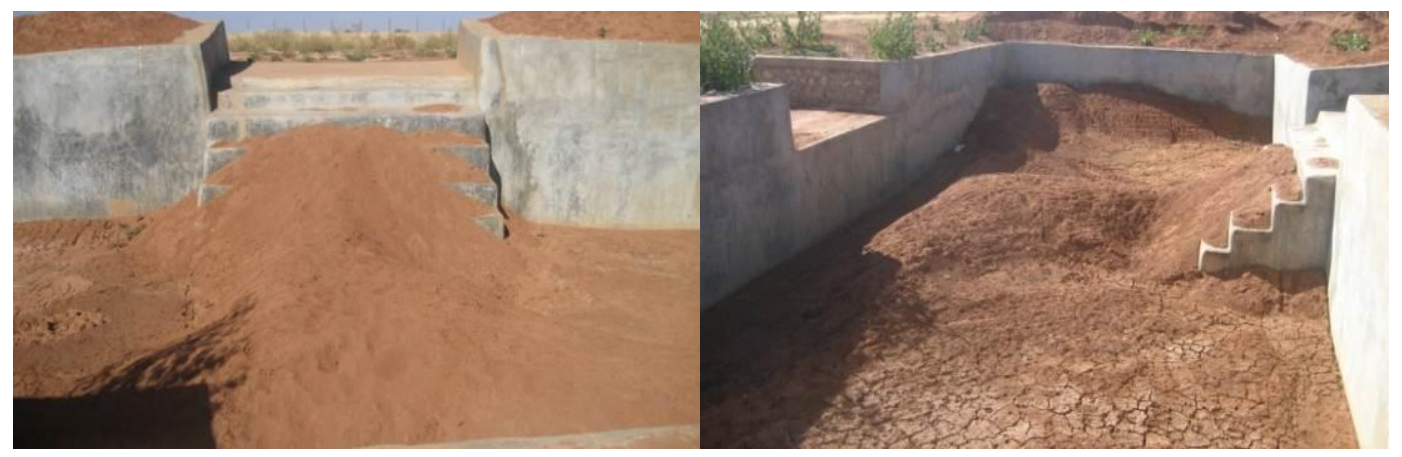

Plate 2. Siltation of Haffir dam in Lankerta

Farming system: Agro-pastoralists with limited mobility of livestock and high frequency of crop failure are more vulnerable to climate change than mobile pastoralists. For example kebeleAbokur in Harshin area are mobile pastoralists with no any private enclosures but communal resources with traditional rules and regulations. The community utilized the spatial and temporal variability of rangelands with diversified livestock. However, such area has attracted some of the agro-pastoralists from the private enclosures that have a double standard. The agro-pastoralists maximized from both private and communal to develop resilience to climate change while pastoralists are confronted with competition of their communal range lands from agro-pastoralists where overgrazing and decline of biodiversity becomes inevitable. The decline of power of the customary institution and some have split their family under the two systems and become difficult to have rules and regulations on the use of communal rangelands.

Underestimating local practices: No due weight has been given to the deep rooted rationality of indigenous practices in livestock rearing and communal resource management. This has attributed to the decline of local resilience to the impact of climate change.

Generally combinations of factors including access to resources, type of livelihoods and indigenous practices have influences on the vulnerability and resilience to the impact of climate change.

\section{Local Innovation in the Adaption of Climate Variability}

Due to the continuous prevailing of risks and uncertainties pastoralists have been 
experimenting, innovating and adapting to the environment and polices changes. Accordingly in the study areas pastoralists have developed some local innovation to enforce their resilience to climate variability and other shocks as indicated below:

\subsection{Early Warning Systems}

\section{Traditional early warning systems}

Under the pastoralist system which is characterized by climate variability in space and time, out of necessity the community has developed a wide range of traditional early warning systems. Some of the indicators are known by the community while others are confined to the specific knowledgeable elderly persons. Usually such knowledgeable people inherited it from their parents. Based on the discussions with elders the following major traditional early warning indicators have been identified:

Behavior changes of domestic animals: Through experience pastoralists have learned livestock behavior as prediction of good and bad seasons. Some of the behavior includes water and pasture demand frequency, pattern of mobility and body weight lose. Some may send to relatives in other areas immediately when they observe changes while others may take some time prior to mobility.

Direction of winds: Already the direction of winds on specific season on their locality indicates the prevailing dry or wet season. Accordingly some split their family and livestock move to the different potential areas beyond their local boundary and across the border.

Vegetation: The flowering and shading of leaves of indigenous trees on specific seasons serves as indicator of good or bad season. Accordingly some will be alert with what they have observed from the vegetation for future planning.

Wild life and insects: different wild animals including birds' change of their habitat and termites direction of movements on the ground are considered to be indicators of the wet or dry season. Usually such observations contribute to be alert and plan for the mobility or sale of some animals.

Astronomical: Where the knowledgeable elderly person will analyze the arrangement of stars on a specific season and time and tell the community member about the season will be good or severe drought. Both the pastoral and agro-pastoralists are still widely practicing the traditional early warnings in the absence of any alternative source of information.

Usually the information on the traditional early warning is shared through the elderly leaders of the local community. The elders select few adult and youth to investigate the rangeland conditions, water availability, prevailing of livestock diseases and security conditions in the areas they plan to move. Accordingly with the feedback of the information the community split their family and livestock and move to different directions. Accordingly the actions on the early warnings vary on the magnitude of drought and conditions of the neighboring areas.

\subsection{Cooperatives as Agents of Changes}




\section{Macrothink}

Already there are more than 17 cooperatives around Harshin areas. All cooperative members have developed a culture of savings and diversification of their economy through the credit access to the members. Significant number of the members dominantly women are engaged on petty trade, running small shops and cross border trades (plate 3). Some of the cooperatives engaged on charcoal making for export have also shifted to other businesses due to the awareness of land degradation problem and risks of livelihoods of the community. In addition to the stimulation of marketing the cooperatives also serve as a destocking and restocking process during bad and good seasons. Moreover, the cooperatives are supporting school and health service developments in their locality, where many female students who use to drop out due to long distance travel and early marriages are now enjoying education and delay early marriages. The cumulative effect is ecological recovery and economic and political empowerment for better resilience to climate change and other pressures

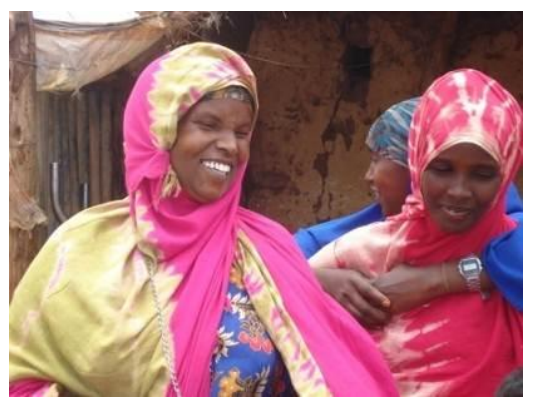

Plate 3. Women cooperative members

\subsection{Appropriate Use of Local Technologies}

Some literatures assumed that pastoralists are backward and reluctant to adapt technologies, yet there are many evidences that pastoralists are adapters of best technologies. Some of the adapted and invented technologies are mentioned as follow:

Use water ponds for nursery and plantation: Some of the agro-pastoralists with private enclosures have constructed ponds and cover with plastic to avoid seepage (plate 4). This water is used for private nursery as centre of seedling multiplication. These seedlings are multi-purpose trees (pasture, medicinal, and edible fruits). Therefore, the biodiversity improves the ecology recovery with biological conservation, soil fertility improvement, creating micro-climate and diversifying economic benefits. In other words the holistic and integrated practice attributes to develop resilience to the impact of climate change. This practice is gradually expanding among the agro-pastoralists. 


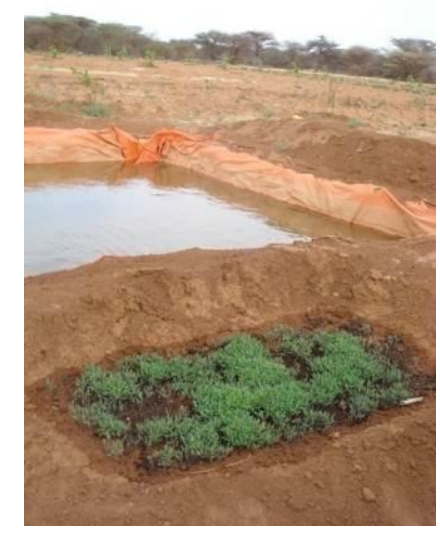

Plate 4. Water ponds for nursery development

Diluting of manure: As a component of intensification of pasture and crop production some of the agro-pastoralists are using diversion ditches to harvest water from roads. Manure is accumulated on the different spots of the diversion ditches to be dissolved and transported to the pasture and crop land during the rainy season (plate 5). This innovative practice is not only improve the fertility of the soil and increase the land productivity and decrease also the labour demand to transport manure to the plots. Therefore, a fertile soil with water harvesting practice is in a better position to develop resilience to climate change.

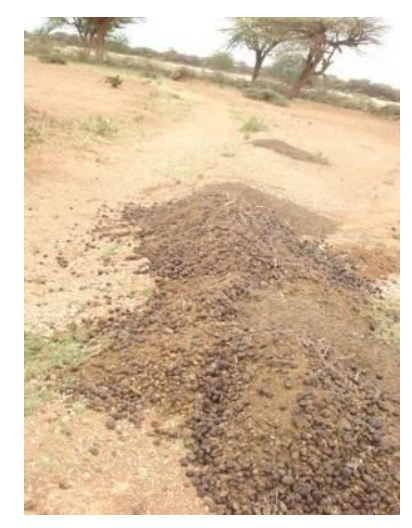

Plate 5. Manure on the diversion ditches to be diluted during rainy season

Use of different animals in ploughing: Usually the agro-pastoralists are ploughing their farm plots with a pair of oxen, while the poor have no pair of oxen to plough. However, an innovative agro-pastoralist who has lost most of his livestock due to drought and diseases remains with a young cattle and single donkey has made a pair and start ploughing his farm plot (plate 6). This practice has multiple benefits; first by ploughing timely with the pair of different animals take an advantage of the early rain and the contour plough also helps to harvest water. Secondly it saves human labour and covers relatively bigger areas for grain and biomass production and thirdly community will take an advantage of the new technology for a better resilience to climate change. 


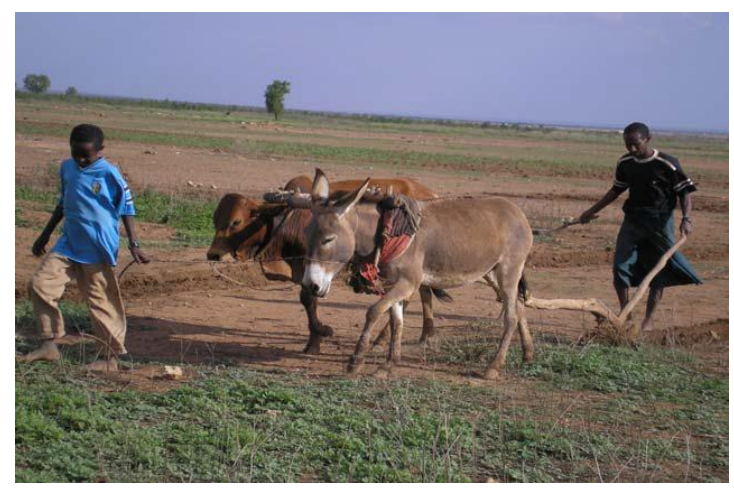

Plate 6. Ploughing with different animals

Adaptation of mobile phones: The use of mobile phones has been widespread among the pastoral community. The traditional early warning information and situation analysis of the neighboring areas prior to mobility including on pasture, water and prevailing of disease are shared to the community with the help of mobile phones. Similarly the mobile phone facilitates livestock market information at different market centers domestically or cross border with merchants and pastoralists. Therefore, the mobile technology ensures safe mobility and access to market information as destocking and restocking strategy on the good and bad seasons (plate 7).

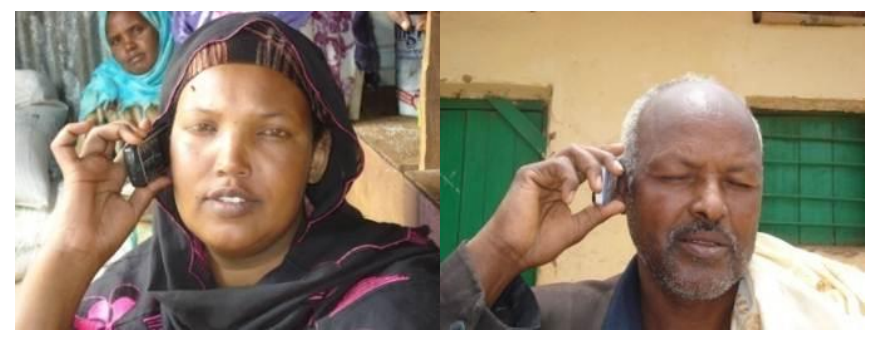

Plate 7. Mobile phones as essential technology on the livelihoods of pastoralists

\section{Conclusions}

Climate change is not a new phenomenon to the pastoral areas and pastoralists have developed some deep rooted experiences and always experiment and innovate to adapt to the environmental and policy changes. Integration of these experiences and innovation in the development process is fundamental in assuring food security and developing resilience to climate change and other pressures.

Similarly pastoral and agro-pastorlism have strong interfaces through the strategy of splitting of family, common use of pasture and water and social safety nets. Hence any interventions in the two sub-systems need to be design with synergetic effect under integrated and holistic approach.

Finally the empowerment of pastoralists in decision making is an opportunity to address their needs and priorities. This is also a step to accommodate pastoralists' values and identities which is embedded in their indigenous practices. Moreover, the different pastoralist polices on land, water development, livestock and crop production need to be reoriented within the 
framework of sustainable development in the arid and semi-arid areas.

\section{Acknowledgements}

The appreciation goes to pastoral community who so generously shared their knowledge and experiences. Oxfam Great Britain creates the opportunity for the study of drought situation in the pastoral areas while the National Metrological Agency and other stakeholders were very cooperative in delivering relevant information.

\section{References}

Abduselam Abdulahi Mohamed (2017). Food Security Situation in Ethiopia: A Review Study, International Journal of Health Economics and Policy, 2(3), 86-96

Adger, N., Agrawala, S., Mirza, MMQ., Conde, C., O'Brien, K., Pulhin, J., Pulwarty, R., Smit, B., \& Takahashi, T. (2007). Assessment of adaptation practices, options, constraints and capacity. In: Parry ML, Canziani OF, Palutikof JP, van der Linden PJ, Hanson CE (eds) Climate Change 2007: impacts, adaptation and vulnerability. Contribution of Working Group II to the Fourth Assessment Report of the Intergovernmental Panel on Climate Change. Cambridge University Press, Cambridge, UK, 717-743

AFI, (2012). Harvest help-African food issues.

http://www.harvesthelp.org.uk/causes-of-food-insecurity-in-african-and-other-third-world-co untries.html.

African Union (2010). Policy framework for pastoralism in Africa, Department for Rural Economy and Agriculture, Africa Union, Addis Ababa

Agnew, C. T. (2000). Using the SPI to identify drought, Drought Network News (1994-2001). http://digitalcommons.unl.edu/droughtnetnews/1

Apata, T. G., Samuel, K. D., \& Adeola, A. O. (2009). Analysis of Climate Change Perception and Adaptation among Arable Food Crop Farmers in South Western Nigeria. Contributed Paper prepared for presentation at the International Association of Agricultural Economists' 2009 Conference, Beijing, China, August 16-22.

ATA, (2010). Accelerating Ethiopian agriculture development for growth, food security and equity. Ethiopian Agricultural Transformation Agency (ATA), 1-116.

Behnke, R. H. (1985). measuring the benefits of subsistence versus commercial livestock production in Africa, Agricultural Systems, 16(2), 109-135.

https://doi.org/10.1016/0308-521X(85)90003-4

Birara Endalew, Mequanent Muche, \& Samuel Tadesse, (2015). Assessment of Food Security Situation in Ethiopia: A Review. Asian J. Agric. Res., 9, 55-68.

https://doi.org/10.3923/ajar.2015.55.68

Butt, T. A., Mccarl, B. A., Angerer, J., Dyke, P. T., \& Stuth, J. W. (2005). The economic and food security implications of climate change in Mali. Climatic Change, 68, 355-378. https://doi.org/10.1007/s10584-005-6014-0 


\section{Macrothink}

Environmental Management and Sustainable Development

ISSN 2164-7682

2017, Vol. 6, No. 2

Christensen, J. H., Hewitson, B., Busuioc, A., Chen, A., Gao, X., Held, I., ... Whetton, P. (2007). Regional climate projections. In: Solomon S, Qin D, Manning M, Chen Z, Marquis M, Averyt KB, Tignor M, Miller HL (eds) Climate Change 2007: the physical science basis. Contribution of Working Group I to the Fourth Assessment Report of the Intergovernmental Panel on Climate Change. Cambridge University Press, Cambridge, UK, 847-940

Central Statistical Agency (CSA). (2008). Summary and statistical report of the 2007 population and housing census. Addis Ababa, Ethiopia. Available at:

http://www.csa.gov.et/pdf/Cen2007_firstdraft.pdf

Davies, J., \& Nori, M. (2008). Managing and mitigating climate change through pastoralism, Policy Matters, 16.

Devereux, S. (2006). Vulnerable livelihoods in Somali Region, Ethiopia. IDS Research Report 57. Brighton: Institute of Development Studies.

Environmental Protection \& Energy \& Mines Resources Development Agency (EPEMRDA) (2011). Climate Change: Impacts, Vulnerabilities \& Adaptation Strategies in Somali Region, Regional Program of Plan to Adapt to Climate Change March 2011 Jigjiga, Ethiopia

FAC-CAADO (2012). Pastoralism in the Horn of Africa: Diverse livelihood pathways, CAADP policy brief, Future Agricultures Consortium (www. Future.agricultures.org)

FAO, (2015). Regional overview of food insecurity: African food security prospects brighter than ever.

Haggman, T. (2006). Pastoral Conflict and Resource Management in Ethiopia's Somali Region. PhD Thesis, Swiss Graduate School of Public Administration(IDHEAP), University of Lausanne

Haile, M. (2005): Weather patterns, food security and humanitarian response in sub-Saharan Africa. Philosophical Transactions of the Royal Society B: Biological Sciences, 360, 2169-2182. https://doi.org/10.1098/rstb.2005.1746

Hesse, C., \& MacGregor, J. (2006):Pastoralism: drylands' invisible asset? IIED Issue Paper 142. London: IIED

Hogg, R. (1997). Changing Land Use and Resource Conflict among Somali Pastoralists in the Haud of South-East Ethiopia, 105-22. In R. Hogg (ed.) Pastoralists Ethnicity and the State in Ethiopia. Haan publishing, London

IPCC, (2014). Summary for policymakers. In: Climate Change 2014: Impacts, Adaptation, and Vulnerability. Part A: Global and Sectoral Aspects. Contribution of Working Group II to the Fifth Assessment Report of the Intergovernmental Panel on Climate Change [Field, C.B., V.R. Barros, D.J. Dokken, K.J. Mach, M.D. Mastrandrea,T.E. Bilir, M. Chatterjee, K.L. Ebi, Y.O. Estrada, R.C. Genova, B. Girma, E.S. Kissel, A.N. Levy, S. MacCracken,P.R. Mastrandrea, and L.L. White (eds.)]. Cambridge University Press, Cambridge, United Kingdom and New York, NY, USA, pp. 1-32. 
Kurukulasuriya, P., Mendelsohn, R., Hassan, R., Benhin, J., Deressa, T., ... Dinar, A. (2006). Will African agriculture survive climate change? World Bank Economic Review, 20, 367-388. https://doi.org/10.1093/wber/lhl004

Little, P. D., Behnke, R., McPeak, J., \& Getachew, G. (2010). Future Scenarios for Pastoral Development in Ethiopia, 2010-2025 Pastoral Economic Growth and Development Policy Assessment, Ethiopia

Manger, L., \& Ahmed, A. G. M. (ed.2000). Pastoralists and environment: Experiences from greater horn of Africa. Proceedings of the regional workshops on Africa dry lands, Addis Ababa and Jinjia. OSSREA, Addis Ababa

Markakis, J. (2004):Pastoralism on margin, minority rights group, London

Mebratu Kigfle (2009). Pastoral land tenure and legislation in Ethiopia. A contribution to the documentation of land tenure and use in pastoral areas of Ethiopia.

National Metrological Agency (2015). Metrological data of Harshin (1979-2014), Somalia Region of Ethiopia, NMA, Addis Ababa, Ethiopia

NMA (2007). Climate change national adaptation program of action (NAPA) of Ethiopia. Addis Ababa: NMA.

Nakashima, D. J., Galloway, McLean, K., Thulstrup, H. D., Ramos, Castillo, A., \& Rubis, J. T. (2012). Weathering Uncertainty: Traditional Knowledge for Climate Change Assessment and Adaptation.Paris, UNESCO, and Darwin, UNU, 120.

Napier, A., \& Solomon, D (2011). Review of Pastoral Rangeland Enclosures in Ethiopia, November 2011, Addia Ababa, Ethiopia

Pavanello, Sara (2009). Pastoralists' vulnerability in the Horn of Africa Exploring political marginalization, donors' policies and cross-border issues - Literature review Humanitarian Policy Group. Overseas Development Institute, London November 2009 www.odi.org.uk/hpg

Pelling, M., \& High, C. (2003): Theory Brief: Institutional theory and societal adaptation to rapid climate change, University of Liverpool

Rettberg, S. (2010). Contested narratives of pastoral vulnerability and risk in Ethiopia's, Pastoralism, 1(2).

Scoones, I. (2004). Climate change and the challenge of non-equilibrium thinking. IDS Bulletin, 35(3), 114-119. https://doi.org/10.1111/j.1759-5436.2004.tb00144.x

Sead Oumer (2007). The 'Privatisation' of Somali Region's Rangelands. 33-44. In Ridgewell, A.,Getachew, M, and Flintan, F (eds) Gender \& Pastoralism Vol 1:Rangeland \& Resource Management in Ethiopia. SOS Sahel Ethiopia, September 2007, Addis Ababa Ethiopia

Simpkin, S. P. (2005) Livestock study in the greatern Horn of Africa ICRC, Novermber 2005, Nairobi, Kenya

Simon Richards, S., \& Gezu, B. (2011). Conflict in the Somali Region of Ethiopia: Can 


\section{Macrothink}

Education Promote Peace-Building? Tufts University, Feinstein International Center

Spore, (2008). Special issue on climate change. http//spore.cta.int

Sugule, J., \& Robert, Walker, R. (1998). Changing Pastoralism in the Ethiopian Somali National Regional State, South East Rangelands Project (SERP), UNDP

Talascan consultant (2009). The impacts of enclosures on access to rangelands, Findings of a cross-border (Somaliland and Somali region) study commissioned by Oxfam Great Britain, April 5.

Taylor, D. R., Olwing, M. F., \& Chhetri, N. (2012). Adaptation as innovation, innovation as adaptation: An institutional approach to climate change, Applied Geography, 33, 107-111. https://doi.org/10.1016/j.apgeog.2011.10.011

Unruh, J. (2006). Common Property and Conflict in Ethiopia: The Case of the Afar, Somali, and Karamojong Cluster Pastoralists, www.dgroups.org

Yohannes, G. M., \& Waters-Bayer, A. (2002). Evaluation of natural resource management programme in the pastoral area of Somalia region, Study commissioned by NOVIB, Addis Ababa, unpublished

Yohannes Gebre Michael, \& Mebratu Kifle (2009). Local innovation in climate-change adaptation by Ethiopian pastoralists. Study for ProlinNovA-Ethiopia, Addis Ababa

Yohannes Gebre Michael, Magagi Saidou, Bayer Wolfgang \& Waters-Bayer Ann (2011). More than climate change: pressures leading to innovation by pastoralists in Ethiopia and Niger, Paper presented at International Conference on future of pastoralism, 21-23. Addis Ababa, Ethiopia

Yohannes Gebre Michael (2015). Opportunities and challenges of government implementation strategies in pastoral areas: Shinile district, Somali Region, Ethiopia, in the intricate road to development: Government development strategies in the pastoral areas of HOA, eds. Yohannes, A and Mahmmud A, IPSS, 152-188

\section{Copyright Disclaimer}

Copyright for this article is retained by the author(s), with first publication rights granted to the journal.

This is an open-access article distributed under the terms and conditions of the Creative Commons Attribution license (http://creativecommons.org/licenses/by/3.0/). 